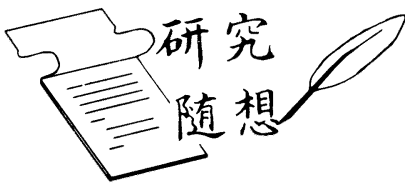

日本機械学会論文集 $(\mathrm{C}$ 編) 71 巻 702 号 $(2005-2)$

実験を振り返っで*

花㠃伸 作 ${ }^{* 1}$

\title{
Think Back to Experiments
}

\author{
Shinsaku HANASAKI*2
}

*2 2-15 Ikagaminami-machi, Hirakata-shi, Osaka, 573-0053 Japan

Key Words : Observation at Experiment, Value of Experiment, Experimental Results against Common Knowledge, Doubt against Common Knowledge, Experimental Proof of Theory, Free Observation of Phenomenon

\section{1. 初期の実験に関して}

著者の研究歴は, 1963 年大阪大学大学院に進学し, 指導教官の長谷川嘉雄先生 (故人) から “ガラス繊維強 化プラスチック (GFRP)の切削 (丸のこ切断)”の研究 テーマを与えられたときに始まる。普及し始めた GFRPは，板材ののこによる耳取で切断開始時には所 要動力は過大でなく切りくず排出も良好であつたが, 切れ刃の摩耗により短時間で切断困難な状態になっ た.なぜそうなるかを明らかにすることが研究の目的 であった．実験に着手してそれまでの常識では説明で きない新しい現象にひかれ，また，他所にはない実験 装置を作る興味, 面白さにもひかれ, 切削の研究に打 ち込むことになった。

GFRP の切削実験には, 平織りガラス繊維強化フェ ノール樹脂板と比較材料としてアルミナ粒子 $4 \%$ を分 散させた綿布強化フェノール樹脂板を使い, 丸のこを モデル化したフライス切削のメカニズムと工具摩耗を 調べた. 工具摩耗の状態を常識の範囲で説明できるア ルミナ粒子分散材に対して, GFRP の切削では常識の 範囲で説明できない現象がいくつも現れた，最も目立 ったのが工具摩耗の切削速度依存性であった．切削速 度が速くなるとともに指数関数的に工具逃げ面摩耗幅 が増加した．これは金属切削の常識からすると熱的な 摩耗である，切削温度を測定したが，実験の範囲内で

* 原稿受付 2004 年 12 月 24 日.

*1 正員, 大阪大学名誉教授 ( $\boldsymbol{\Psi}$ 573-0053 枚方市伊加賀南町 215).

[著者略歴］1940 年 4 月 5 日生まれ，主として機械工作，特に GFRP 等瀻維強化複合材料の切削, プラスチックの成形加工, 金属切削・研削，ツイストドリルによる穴あけの研究に従事， 2004 年 3 月まで大阪大学, 現在無所属.

E-mail : hanasaki@mech.eng.osaka-u.ac.jp
は熱的な摩耗が生じる温度ではなく, 工具摩耗が機械 的な摩耗特性のアルミ十粒子分散材の方が切削温度が 高かった。

\section{2. 観察からカ学モデル}

工具摩耗形状の観察からガラス繊維の曲げ剛性の影 響が考えられ, ガラス繊維の曲げ剛性とガラス瀻維を 固めている樹脂の粘弹性の組合せ効果を力学モデルと した理論解析で, 工具摩耗が機械的な摩耗でありなが ら強い切削速度依存性の生じるメカニズムを説明する ことができた。しかし，あくまで熱的な摩耗であると の強い意見があり, 別の観点から熱的な摩耗でないこ とを証明するための実験をいくつも行った。すなわ ち, ガラス短瀻維とガラスビーズを同じ含有率で含む 2 種類のプラスチックの切削で, 切削主分力 (発熱量, 温度上昇)が同レベルであるのに, ビーズ含有材では 特定の切削条件範囲以外は工具摩耗にガラス瀻維強化 材のような強い切削速度依存性がないこと, 摩耗部断 面形状が温度の高い摩耗部後半部で出張っている(摩 耗が少ない)こと, GFRP を加熱切削すると工具摩耗 が軽減されるのに対して水溶性切削液で湿式 (冷却) 切 削すると工具摩耗が増加することなど，これらの結果 (ビーズ含有材の特定切削条件範囲内での結果以外) は 理論解析の結果で説明できた。 その後, 工具摩耗につ いて強い切削速度依存性だけでなく常識の範囲では説 明できない他の実験結果を併せて検討し，理論解析を 広くまとまった形にして強い切削速度依存性だけでな く送り速度もしくは切り込みの影響(ガラス緎維の方 向によって影響が異なる)も説明できた。この理論は 後に行った実験で GFRP と同様の材料構造でありな がら工具摩耗特性が異なるように見える CFRP 切削 
時の工具摩耗特性も説明できた。

\section{3. 実験の重要性}

ある理論(考え)を実験で証明する場合, その理論が どこまで適用できるかを明確にした上で, 証明するた めの実験は適用範囲内の広い条件で行う必要がある. この意味で,こだわる知識体系ができていない研究活 動開始段階で，常識の範囲内では説明できない現象を 示す実験に携わったことは幸いだったと考えている. 広い条件とは観点を変えた見方と考えることもでき る.一つの考えにこだわっていると「精度の高い証明 実験」との意識から，無意識のうちに限定された狭い 条件で証明実験を行ってしまうこともある.GFRP の切削に関する研究にはかなりの年数をかけ，また議 論を行った結果として，「一つの実験で色々な面から 現象を見る.一つの考えにこだわりすぎない」を体得 することができた。

実験はシミュレーションと異なり, 実験条件を間違 えてもその実験条件では現実に存在する現象を観察で きる.そして, 結果的に重要な実験結果を得ることも ある、また，計画した実験の結果が予想通りにならな いことも多い. 実験条件を正確に認識して現象を把握 することが大切である．金属切削でも一見常識に合わ ない現象 (予想通りでない結果)にいくつも出会ってい る.

\section{4. 実験結果と常識}

ツイストドリルによる穴あけでは, 初期に生成され る円すいらせん形切りくずは, あけている穴の壁に接 触していないと切りくず内の相互干涉以外は無拘束で 自由な切りくず生成とされていた. ドリルの形状から 主切れ刃外端は内端と比べすくい角が大きく, 切削速 度は速い.したがって, 無拘束円すいらせん形切りく ずの外端部は内端部に比べ切削比が大きいことにな る. 円すいらせん形切りくずの内・外端部の厚さ測定 結果はこの考えに合っていた。この円すいらせん形切 りくずを縦に二分するニック付きドリルの内側部, 外 側部切れ刃による円すいらせん形切りくずのピッチは
ニックなしドリルのピッチより大と小にならなければ ならないが, 両方とも大である.

別のドリル実験で, 円すいらせん形切りくずの 2 ピ ッチ分の質量, 外径, 内径, ピッチを測定し, 切削幅が 切りくず幅に等しいとの仮定のもと, 内・外端部の切 削比を求めた. 比較のため測定した慣用ドリルの円す いらせん形切りくず内端部の切削比は約 1.0 という大 きな值であった.よく観察すると, 穴あけ初期の円す いらせん形切りくずはドリル溝の強い拘束を受けてい る.これはその結果である.この結果から, 測定され ていた切りくず厚さは, 外端部は問題なく通常の誤差 の範囲の測定値であるが, 内端部はのみ刃部から押し 出された部分を測定したもので, 測定対象に合わない 部分であったと考えられる. 円すいらせん形切りくず が拘束を受けているのであれば, ニック付きドリルの 切りくず形状は納得できるものである.

主切れ刃近傍のみすくい角を 0 度にした心厚の厚い ドリルで，ねじれたリボン状の切りくずが円すいらせ ん形切りくずに続いて発生した. この実験結果を基に モデル化した二次元切削実験でも一見常識に合わない 結果を得た，狭いすくい面幅のすくい角 0 度工具によ る二次元切削で, 切りくずのカールを抑制する板をす くい面と平行に設置する。これは切りくずの拘束であ るから切りくずの排出を抑制するように見える，切り くず流出速度が遅くなればそれは切削比が小さくなっ たことである．切りくずカールの抑制を切りくず排出 抑制につなげて考えると切削比は小さくなるはずであ る.しかし, カールの抑制状態によっては切削比が大 きくなった.これは切りくずカール抑制によって切り くずが“てこ”の作用でせん断力を刃先部に集中する 効果が生じるが, 切りくずカール抑制状態によっては この切りくず “てこ”の作用が切りくず排出抑制効果 よりも大きくなるためである.

一見常識に合わない現象というのは，それを説明す る論理の展開に飛躍があり, 見落としている点がある ことだと考えられる。このことは「常識を疑え」とい う言葉につながっているとも考えられる。 